\title{
Principal Leadership, School Climate, and School Productivity at Vocational School in Bandung
}

\author{
A. Sobandi, Udin S. Saud \\ Universitas Pendidikan Indonesia \\ Bandung, Indonesia \\ ade@upi.edu
}

\begin{abstract}
This article analyzes the lack of productivity of Vocational High School (VHS) of Business and Management Expertise in Bandung. This shortage is due to the lack of involvement of VHS graduates in the world of business and industry, that impact on the rate of unemployment in Indonesia, which is a major phenomenon of productivity of VHS. The aim of this article is to analyze the effect of principal leadership and school climate on school productivity in Vocational High School of Business and Management Expertise in Bandung. The method of research is explanatory survey using questionnaire as data collecting technique. The respondents are 1,236 teachers from 40 vocational schools. The data were analyzed using multivariate regression. The founding of this research is that: the principal leadership has a positive and significant influence on school productivity of VHS of Business and Management Expertise in Bandung, the school climate has a positive and significant influence on productivity of VHS of Business and Management Expertise in Bandung, and the principal leadership and school climate have a positive and significant influence on productivity of VHS of Business and Management Expertise in Bandung. To enhance the productivity of VHS, it is recommended that the principal to optimize the supporting elements in school environment, i.e. the school climate.
\end{abstract}

Keywords- Principal leadership; School Climate; School Productivity; Vocational High School

\section{INTRODUCTION}

School, as a social organization, is expected to meet the expectations and needs of the community regarding the quality education that is able to prepare the resources to compete in an increasingly complex world. For this purpose, the school productivity should be the main requirement, because of the general characteristics of the productive school can be seen from the character and nature of the school organization, whether it can provide the opportunity to achieve high productivity.

Vocational High School (VHS) should be able to prepare creative students, master of science and technology, and has competence compliant with the demands of the working world. Vocational schools do not only establish the cognitive abilities, but also shape the mentality of students to be integrated with practical and theoretical skills, and the compilation of both. Thus, vocational schools could bridge the problems of the working world in Indonesia.
In fact, the productivity of VHS in Indonesia is still not optimal. Education in Indonesia has experienced four fundamental crises: quality, external relevance, elitism and management [1]. In particular, the external relevance in VHS remains a problem, with regard to the large number of unemployed graduates from VHS in Indonesia. In West Java, in 2015, the labor force is dominated by primary school graduates $(37.23 \%)$, followed by secondary school graduates (including VHS) (19.66\%), while higher education is still relatively small (8.23\%) [2]. It is assumed that the productivity of several vocational schools of business and management expertise in Bandung is not optimal. The number of graduates who cannot be absorbed by the business/industrial world is due to the competence of the graduates that are not optimal, which is one indication of the school productivity.

Many factors affect the school productivity, such as the quality of the learning process, the competence of teachers, school organization culture, school climate, school finance, principal leadership, and school committees [1][3][4][5]. In this case, principal leadership and school climate are the major factors in achieving the school objective and productivity. The school principal is one of the main components of education in improving the quality of education. School principal is closely related to various aspects of school life such as school discipline, climate, and culture [6]. School climate is the quality of the school environment that is constantly experienced by the teachers regarding the physical environment and non-physical jobs that evoke comfort and satisfaction in working place [7].

Productivity is measured by a combination of effectiveness and efficiency [8]. Productivity is not production, not performance, nor results. Production, performance, and the result are the components of productivity. In this sense, productivity is how to produce or improve the results of goods and services as high as possible by utilizing resources efficiently and effectively. Productive school can be seen in three dimensions: input, transformation process and output [7]. Input comes from monetary and non-monetary. Sources of monetary are taxes, fund, or objects that could be purchased with money. While non-monetary standards and policies include education, political structure, organization plan, the support of parents and student intake. Transformation process is influenced by cultural system, structural system, political system, and individual system. Output implies that the 
effectiveness of education provision will impact on achievement, job satisfaction, absenteeism, dropout rates, and school quality.

Measuring school productivity is not the same by measuring productivity at companies that produce goods. There are five dimensions in a productive organization including school: a) has the clarity of the objective function with measurable outcomes; b) the existence of incentives associated with success; c) access to efficient information; d) able to adapt; and e) use technology productively to save costs [9]. In this case, the school productivity is an overall planning, structuring and utilization of resources to optimally realize the goal of the school, including the function of economic, political, social, cultural and educational, with dimensions of: (a) the production function of administrator; (b) the production function of psychology; and (c) the production function of economic [1][7][8].

There are several aspects that must be maintained on school leadership [10]. Successful school leadership is able to make an important contribution to the improvement of student learning. The main sources of successful leadership at the school are principal and teachers. The school leadership must also be distributed to others in the school community. The inner core set of valuable leadership practices can be applied in nearly all contexts, such as set the direction, identify and articulate the vision, encourage acceptance of the group's goals, create high performance expectations, develop people, offer intellectual stimulation, providing individual support, provide an appropriate model, redesign the organization, set the school culture, modify organizational structure, and build collaborative process. In addition to engaging in a series of core leadership practices, successful leaders must act to acknowledge the context of accountability-oriented policy in virtually all jobs, especially in terms of market accountability, decentralization accountability, professional accountability, and management accountability.

Leadership behaviors that are relevant to the process of motivation are supportive leadership, directive leadership, participative leadership, and achievement-oriented leadership [11]. Effective leadership behaviors will engage three attentions or objectives: task-oriented, relationship-oriented, and change-oriented [12]. Principal leadership in this research is specific actions of the principal in the organization of school activities in accordance with the principal capabilities. Dimensions of school leadership can be seen in terms of achievement-oriented leadership, directive/incremental leadership, participative leadership, and supportive leadership [7] [10] [12] [13].

First, the dimension of achievement-oriented leadership is where the leadership of the principal set challenging goals and expects subordinates to excel as much as possible as well as continuously seeking development achievements in the process of achieving that goal. This dimension includes teachers involved in school activities, priority on execution and excellence, emphasis on teacher performance standards, improving teacher performance, and has the confidence. Second, the dimension of directive/incremental leadership is the ability to direct subordinates to work in accordance with the rules, procedures and instructions. Third, the dimension of participative leadership is the power equation in solving problems and sharing with subordinates, by way of consultation with subordinates before making a decision. Fourth, the dimension of supportive leadership is the leadership that shows concern for the welfare and needs of employees, being friendly and approachable, and treating subordinates as equals with the principal.

Organizational climate is a general concept that reflects the quality of life of the organization. The quality of life of the organization studied from various viewpoints. One of the concepts and measurement of organizational climate can be evaluated from the behavioral aspects of leadership and subordinates. Behavior in any organization has a complex function, because in it there are a number of individual needs and organizational objectives to be achieved collectively. Relations among the elements in it are very dynamic; they bring unique practices with symbols, values and motivations. The behavior of the organizational climate that comes from the leadership (principals) is supportive, directive, restrictive, and the behavior that comes from subordinate (teachers) is a collegial, intimate and disengaged. The combination of these dimensions produce four organizational climate: open, engaged, disengaged and closed. The level of openness of the teachers is one of the categories of organizational climate which is called the 'Open Climate' [7].

In short, school climate is the atmosphere or conditions in the school created by the pattern of interpersonal relationships in effect on the organization of the school. The pattern of the relationship stems from the relationship between teachers with other teachers or the relationship between teachers and the school principal or vice versa between the principal and teachers. This study focuses on the dimensions of school climate that have high transparency and are considered quite essential: supportive, collegial, intimate, and cooperative [7].

First, supportive climate illustrates that people in the work of mutual respect, mutual encouragement and attention. Choice is reflected in attitudes of respect and criticism constructively addressed. People respect of professional competence. The behavior of teachers is reflected in terms of: a) the teachers respect the achievements in the work; b) the teachers have such empathy; c) teachers are to give each other a boost in work. Second, collegial climate describes intimacy, friendship, enthusiastically working to enhance professional competence. The behaviors of the teachers will be as follows: a) the teachers sharing of ideas in solving the problems of the school; and b) mutual trust among teachers. Third, intimate climate describes the atmosphere of strong solidarity, mutual respect, and high tolerance level. The behaviors of the teachers are reflected as follows: a) the teachers have a high level of solidarity; b) mutual respect among teachers; and c) the teachers have a high tolerance level. Fourth, cooperative climate describes the degree of cooperation, solidarity and mutual help among teachers in completing tasks in an effort to improve the effectiveness of the achievement of organizational goals. The behavior of the teachers will be as follows: a) the teachers have a willingness to help each other in work; b) togetherness among individual teachers in their work; and c) teachers work together in performing the task. 
The problem formulation in this research is how the influence of school leadership and school climate, partially or simultaneously, on the school productivity of VHS of Business and Management Expertise in Bandung. The study focuses on three variables:

- School Productivity (Y), which comprises three dimensions: (a) the production function of administrator; (b) the production function of psychology; and (c) the production function of economic.

- Principal Leadership (X1), which comprises four dimensions: (a) achievement-oriented leadership, (b) directive/incremental leadership, (c) participative leadership, and (d) supportive leadership.

- School Climate (X2), which comprises four dimensions: (a) supportive, (b) collegial, (c) intimate, and (d) cooperative.

The hypotheses testing are proposed as follows:

- Principal leadership has influence on school productivity.

- School climate has influence on school productivity.

- Principal leadership and school climate have influence on school productivity.

Based on those hypotheses, relationships among variables can be illustrated as follows.

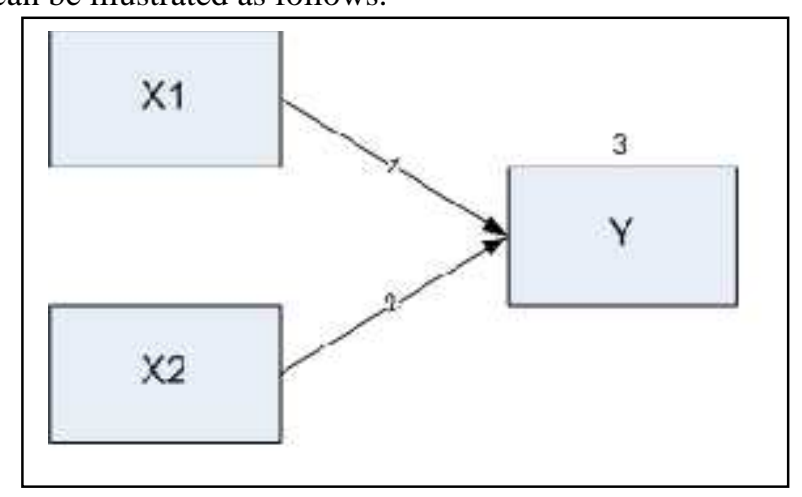

Fig. 1. Relationship among Variables

\section{METHOD}

This was a descriptive-verification research with quantitative approach. The design of study had constructed a model of equation:

$$
Y=f(X 1, X 2)
$$

Notes:

X1: Principal Leadership

X2: School Climate

Y: School Productivity
The method of research is explanatory survey using questionnaire as data collecting technique. The respondents are 1,236 teachers from 40 vocational schools of Business and Management Expertise in Bandung. The data were analyzed using multivariate regression. Before testing the hypothesis, some statistical assumptions need to be fulfilled, namely normality, multicollinearity, and heteroscedasticity. Based on those tests, it was found that the data were normally distributed, had no problem with multicollinearity (linear), and had no problem with heteroscedasticity (homogeneous). Thus, all the requisite statistical assumptions are met and can be continued by hypotheses testing using regression analysis.

\section{ANALYSIS OF FINDINGS}

This section outlines a description of the variables studied, with the help of descriptive statistics to present a summary of the data of the average achievement scores, percentages, and categories for each indicator and dimension of the variables. Below are presented details of the achievements of the average score of each variable in 40 vocational schools.

TABLE I. AVERAGE SCORES OF VARIABLES

\begin{tabular}{|l|l|l|l|}
\hline \multirow{2}{*}{ Variables/ Dimensions } & \multicolumn{3}{|c|}{ Measurements } \\
\cline { 2 - 4 } & \multicolumn{1}{|c|}{ Average } & \multicolumn{1}{|c|}{ Percentage } & \multicolumn{1}{c|}{ Category } \\
\hline Principal Ladership (X1) & 3.926 & 78.5 & High \\
\hline $\begin{array}{l}\text { Achievement-oriented } \\
\text { leadership }\end{array}$ & 4.073 & 81.5 & High \\
\hline $\begin{array}{l}\text { Directive/incremental } \\
\text { leadership }\end{array}$ & 3.946 & 78.9 & High \\
\hline Participative leadership & 3.849 & 77.0 & High \\
\hline Supportive leadership & 3.862 & 77.2 & High \\
\hline School Climate (X2) & 3.849 & 77.0 & High \\
\hline Supportive & 3.614 & 72.3 & High \\
\hline Collegial & 3.826 & 76.5 & High \\
\hline Intimate & 3.908 & 78.2 & High \\
\hline Cooperative & 4.049 & 81.0 & High \\
\hline School Productivity (Y) & 3.892 & 77.8 & High \\
\hline $\begin{array}{l}\text { Production function of } \\
\text { administrator }\end{array}$ & 3.964 & 79.3 & High \\
\hline $\begin{array}{l}\text { Production function of } \\
\text { psychology }\end{array}$ & 3.945 & 78.9 & High \\
\hline $\begin{array}{l}\text { Production function of } \\
\text { economic }\end{array}$ & 3.767 & 75.3 & High \\
\hline
\end{tabular}

The table shows that in general the Principal Leadership is perceived highest by respondents, followed by School Productivity, and School Climate. The principal leadership was perceived high because most respondents saw that this leadership component is basically a driver or enabler variable, which allowed all components of school to operate. In other words, the more effective school leadership, the more conducive school climate, and in turn the school productivity at vocational school of Business and Management Expertise in Bandung can be improved. 
The hypotheses testing in accordance with the proposed model can be summarized as follows.

TABLE II. SUMMARIZED OF HYPOTHESES TESTING

\begin{tabular}{|c|c|c|c|c|c|}
\hline \multirow[b]{2}{*}{ Model } & \multicolumn{5}{|c|}{ Summary } \\
\hline & Estimate & $\begin{array}{c}\text { Standard } \\
\text { Error }\end{array}$ & $\begin{array}{c}\text { Critical } \\
\text { Ratio }\end{array}$ & $p$-value & Sig. \\
\hline $\mathrm{Y} \leftarrow \mathrm{X} 1$ & 0,341 & 0,033 & 10,372 & 0,000 & Sig. \\
\hline $\mathrm{Y} \leftarrow \mathrm{X} 2$ & 0,320 & 0,036 & 8,815 & 0,000 & Sig. \\
\hline $\begin{array}{l}\mathrm{Y} \leftarrow \mathrm{X} 1, \mathrm{X} 2 \\
(\text { simultaneous) }\end{array}$ & \multicolumn{4}{|c|}{$R^{2}=0,403 ; \varepsilon=0,597$} & Sig. \\
\hline
\end{tabular}

The table shows that all hypotheses can be accepted. These findings support and reinforce previous researches related to the effect of principal leadership and school climate on school productivity. On the whole, the diagram can be illustrated as follows.

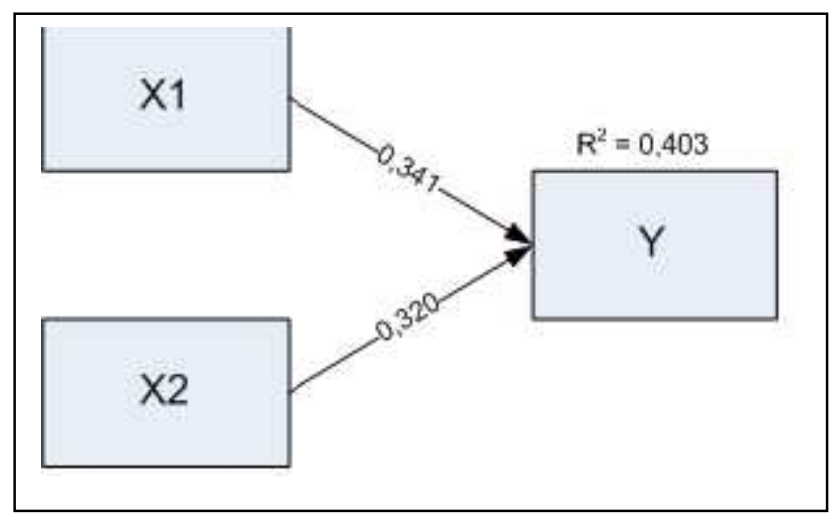

Fig. 2. Overall Model

The results generally show an indication of the influence of exogenous variables on endogenous variables in positive and meaningful ways. School productivity, directly and indirectly, is significantly influenced by principal leadership and school climate. Directly, the biggest influence on school productivity is principal leadership, followed school climate. It indicates that principal leadership is an important component in driving others components to improve the school productivity. In brief, school productivity will be high if supported by the presence of effective school leadership, which can improve school climate.

The role of the principal as a leader who can move his subordinates and all members of the learning activities in the school environment should be able to set a common direction, empowering human resources and develop organizational culture in the school environment. Learning activities therein involves the teacher's role in generating an effective learning process, school climate that is conducive and learning facilities as a tool to help a teacher to be able to carry out any activity with the learning process is good and conducive. The higher the contribution made by the school principal will also increase the response generated to the school productivity.
School productivity can be established if the school leadership can perform their duties and responsibilities in accordance with the vision and mission. Given the leadership role can be full of actors acting in motivating members of the organization of the school, especially teachers as an educational force that has full authority in teaching and learning activities of students in the classroom. The role of school leadership can not only motivate its members, but it became the controller in the utilization of school resources, especially in managing learning facilities. Learning facilities is a very important instrument in supporting any learning activities undertaken by teachers, so it must be managed properly.

Results of testing hypotheses derived from empirical evidence is supported by the other research, which shows that the productivity will increase when supported by the appropriate leadership style and optimal workability and good motivation [14]. Principals can improve the ability and motivation to carry out the task of leadership which in turn can increase the productivity of better schools. The factors that reduce productivity are: (a) the performance of principals who do not have a clear vision and mission; (b) an organizational culture that is not conducive school; and (c) the competence of teachers is not optimal, and the limited facilities and infrastructure in schools [15].

Leaders who are expecting an increase in productivity should realize the importance of the contribution of the school principal, the teaching performance of teachers, school climate and learning facilities in an effort to increase it. All of these components are key components are interrelated in the school productivity improvement. High and low productivity is largely determined by the seriousness of the school principal's leadership in moving the other key components that affect the productivity of the school. Leadership behaviors of principals in their role as instructional leaders have a significant impact on the creation of effective schools and student achievement [17].

In general, teachers as respondents in this study assumes that the school climate affect the productivity of the school. School climate is one element in the creation of the school productivity. School climate has a strong influence in creating another element conducive and effective. School climate that is conducive can enhance the learning process; it is because the school climate reflects the performance of professional teachers and this is an impact to students and to the teaching and learning in the classroom. Thus the school climate positively affects the productivity improvement of the school.

School climate that is conducive and harmony between teachers, administration staffs, students, the community and other resources will create a synergistic performance, a solid partnership between the school communities that the school productivity increases. Conducive school climate atmosphere that is safe, comfortable, orderly, there will be learning with enjoyable and pleasant learning. A positive school culture is associated with the motivation of learning and high student achievement, increase collaboration among teachers, and changing teacher attitudes towards work to be positive [13]. In the context of a school with a strong culture, it is characterized 
by learning attractive, conducive, productive, and enjoyable. The conclusion is that the result of empirical research and the fact that according to the theory, expert opinion, as well as the results of previous studies which stated that the school productivity is significantly affected by the climate of the school.

\section{CONCLUSION}

Principal leadership in VHS of Business and Management Expertise in Bandung is not optimal in the aspect of participatory. In general, the principal has been able to apply the leadership that involving the principal in the two-way communication, listening, encouraging, and involving staff and members of the school in problem solving and decisionmaking, but the principal is not optimal in implementing participatory leadership, which means the principal need to improve the clarity of the mechanism of various procedures of decision that gives other people a certain influence on the decision of the principal. Principal in VHS of business and management expertise in Bandung may apply leadership that provide challenges with attractive missions for members of the school, including teachers, staffs, and students, who can be motivated to achieve these goals and perform well, provide clear goals to be achieved by the school, be open, and build collaborative relationships that enable all staff and teachers to involve in any decision-making.

\section{References}

[1] P. Thomas, The determinant factor of the school productivity. Journal of Educational Research and Evaluation, 17(1), 2013, pp.55-66.
[2] Press Release West Java Province No. 31.05.32. year XVII.

[3] A.J.W. Mahri and M. Arief Ramdhany, The Influence of Principal's Leadership on Teachers' Competency, Motivation and Job Satisfaction, And Its Implication on Teachers' Performance in West Java. Jurnal Pendidikan Bintara UPSI. Vol. 6/2013.

[4] Aan Komariah, Transformational Leadership, School Climate, Teacher Performance and Productivity School http://ejournal.unisba.ac.id

[5] Y. Saparudin, Productivity Development in Madasah. Jurnal Administrasi Pendidikan. 13(2), 2012, pp.16-25.

[6] D. Supriyadi, Raise the image and dignity of teachers. Yogyakarta: Adicita Karya, 1999.

[7] Wayne K. Hoy \& Cecil G. Miskel. Educational Administration: Theory, Research, and Practice (6th edition). New York: McGraw-Hill Companies, Inc, 2001.

[8] P. Mali, Improving Total Productivity; MBO Strategy for Business, Government, and Non Profit Organization. New York: John Wiley \& Sons, 1978.

[9] Levin HM. Economics of Education, The. Alb. Gov't L. Rev.. 2011;4:394.

[10] Leithwood, K. A. \& Riehl, C., What We Know About Succesfull School Leadership, PA: Laboratory for Student Success. Philadelphia: Temple University, 2005.

[11] House R. J., A Path-Goal Theory of Leader Effectiveness, Administrative Science Quarterly, 16, 1971, pp.321-338.

[12] Yukl, G., Leadership in Organization. Fifth Edition. Jakarta: Indeks, 2009.

[13] Danim, S., New Vision of School Management: From Bureaucracy to Academic Institutions. Jakarta: Bumi Aksara, 2006.

[14] Faustino Cardoso Gomes, Human Resources Management. Yogyakarta: Andi, 2009.

[15] Rois, Organizational Behavior. Malang: Bayu Media, 2003.

[16] Gentilucci, J.L., \& Muto, C. C., Principals' Influence on Academic Achievement: The Student Perspective. The National Association of Secondary School Principals. Education Journal, 2007, p. 232. 